Марко Чудић

Универзитет у Београду

Филолошки факултет
УКД 821.511.141:004.738.5

дОИ https://doi.org/10.18485/

melissa.2016.15.1.ch15

\title{
НАЈВАЖНИЈИ МАЂАРСКИ КЊИЖЕВНИ ИНТЕРНЕТ-ПОРТАЛИ
}

\section{Сажетак}

У овом раду се разматра однос интернета и мађарске књижевности, са посебним освртом на најважније интернет-портале посвећене класичној, модерној и савременој мађарској књижевности. У фокусу овог, у првом реду информативног рада, налазе се пре свега званични интернет-сајтови попут Дигиталне књижевне академије (Digitális Irodalmi Akadémia), на којој су похрањена дигитализована дела одабраних (канонизованих) савремених аутора. Поред тога, рад се фокусира и на алтернативније књижевне интернет-сајтове попут блогова, на којима влада нешто већа „демократичност“ критичког мишљења (у смислу да практично било који читалац може изнети своје мишљење о неком делу), али и на оне форуме и блогове који нуде алтернативна читања класичних дела. Посебна пажња у излагању посвећена је онлајн мађарској књижевној периодици, као и односу српских студената хунгарологије према мађарској књижевности на интернету.

Кључне речи: мађарска књижевност, интернет, књижевни блогови, канонизација, алтернативна критика

Чини се да две опречне тенденције свеопште интернетизације културе - неумитно потврђивање „закона јачег” у смислу да се већ тим фамозним једним кликом у први план истичу доминантни језици и културе с једне, али и свеопшта демократизација и доступност културних добара из свих крајева света, с друге стране - нигде нису тако снажно присутне и заоштрене као у случају мањих језика и култура. Није спорно да мађарска култура, иако је реч о значајном и језички и културолошки веома специфичном средњоевропском културном корпусу, спада у ту групу мањих култура. Пре појаве интернета, мађарски писци, литерате и културни посленици често су (и, додајмо, са правом) истицали, данашњим политичким жаргоном казано, два 
главна стуба недовољног уважавања заиста, у светским размерама врхунских остварења мађарске књижевности, како класичних, тако и савремених. Један од тих стубова био је идеолошко-политички: земља је, практично, готово читав кратки двадесети век, од 1919. па све до 1989. године, била под влашћу тоталитарних, од света изолованих режима, прво фашистичког, а онда и комунистичког. У овај први, идеолошко-политички разлог недовољне уважаваности мађарске књижевности, могла би се додати и неспособност, односно недовољна утицајност мађарских културних радника у земљи и иностранству, да глас о тој књижевности шире. И не само неспособност у смислу недовољног културног „лобирања”, већ и идеолошка острашћеност, како оних културних радника у матици, тако и дисидената на Западу. Као други, пак, стуб на којем је почивао тај недостатак одјека, истицао се сам мађарски језик, као неиндоевропски и стога тежак и непривлачан за учење полиглотима индоевропске (славистичке, романистичке или германистичке провенијенције). Некомуникабилност врхунских мађарских песничких остварења често је (такође с правом) приписивана језичким специфичностима и могућностима мађарског језика које су се, практично, проглашавале непреводљивим. Отуд, рецимо, комплексна поезија великог, култног песника двадесетог века, Атиле Јожефа, који је био много више од пуког идеолога хумане левице, у неким земљама (као на Куби, на пример) добија само то једнодимензионално, идеолошко читање.

Са појавом интернета и све већом дигитализацијом културне баштине, све осетнијом демократизацијом знања и доступношћу информација, те све већом демистификацијом лажних (често идеолошки обојених) ауторитета и књижевних арбитара, чини се да се темељи првог стуба којим се објашњавао тај ламент над некомуникабилношћу мађарске књижевности, полако, али сигурно подривају, са перспективом да се у будућности и потпуно сруше. Нема сумње да је други стуб, језик, много чвршћи и жилавији, упркос све очигледнијем развоју методологије учења страних језика. Рушењу другог стуба се, уосталом, из сасвим очигледних разлога, и не може тежити, јер би то онда поништило и само постојање мађарске књижевности као такве, са свим њеним (и) из језика про- 
истеклим специфичностима. Михаљ Сегеди-Масак, професор који је предавао и на америчким универзитетима и који је из прве руке могао да се увери у (не)могућности рецепције мађарске књижевности у другим, већим културама, управо истиче језик као највећу препреку за разумевање и подвлачи да је премало оних преводилаца који нису људи мађарског порекла, да је међу преводиоцима мађарске књижевности дакле премало оних изворних говорника енглеског и других великих језика који би умели, својом уроњеношћу у циљну културу и својом истински матерњејезичком компетецијом, да створе преводе који су у правом смислу те речи уметнички (SzegedyMaszák Mihály, 2003: 15): „Тешко је порећи да се вредности мађарске књижевности у већини превода губе. [...] Велики је пропуст што се преводи са мађарског ретко када оцењују. Овај недостатак се вероватно може објаснити тиме да би такав оцењивач морао да се осећа код куће у двема културама. Признајем да досад једва да сам имао прилику да се сретнем са двојезичним људима у правом смислу речи. Већини људи који преводе са мађарског матерњи језик је мађарски. "У том погледу, мађарска култура дели усуд већине малих средњоевропских култура, која се огледа у чињеници да међу припадницима великих народа истински заинтересованих стручњака за те културе једва да и има, те да мање-више само људи који потичу са ових простора, а који су емигрирали на Запад, преводе дела ових књижевности на стране језике, сматрајући то својим дугом према отаџбини и њеној култури. Проблем је, међутим, у томе, што они преводе на језике који су често и њима самима (још увек) страни, а подједнако велики проблем је и њихово суштинско непознавање културе у које тако преведено дело ступа.

Ако се пође од претпоставке, у данашње време нарочито актуелне, да свака земља, свака нација поседује, суштински, два различита нивоа културних добара, или, још прецизније формулисано, два различита нивоа перцепције културних добара, онда би се та дихотомија перцепције са пуним легитимитетом могла применити на књижевност, која због саме своје природе свакако не може да се сврста у категорију визуелног спектакла. Први, доступнији и тиме површнији ниво перцепције назваћемо туристичким. У том смис- 
лу, туристички је, рецимо, ниво перцепције архитектуре или ликовне уметности који се задовољава прављењем селфија са кривог торња у Пизи или у друштву Мона Лизе у Лувру. Кад је реч о књижевности, у туристички ниво перцепције могло би да спада површно познавање највећих имена једне литературе или познавање неке литературе само на основу пколске лектире или преведених дела. Није нимало утешна чињеница да такав туриста човек може бити и у властитој култури и књижевности. Други ниво перцепције културних добара, односно, у овом случају, књижевности, назвали бисмо, у недостатку бољег израза, дубинским нивоом перцепције. То је она врста перцепције која карактерише упућеника у неку културу, њеног доброг познаваоца. Већ смо видели да познавање језика (чак и ако је на нивоу матерњег) не гарантује дубинску перцепцију, те да човек може бити туриста и у властитој култури, а посебно у књижевности. Па ипак, нарочито кад је реч о мањим културама и књижевностима, добро знање датог језика јесте предуслов, иако не и гаранција, дубинског нивоа перцепције. За преводиоце или потенцијалне преводиоце би, рецимо, способност дубинске перцепције морала бити од нарочитог значаја, нарочито у интернет ери свеопште доступности (књижевних) информација, будући да (само)заваравање илузијом првог клика може довести до неопростивих промашаја у избору и наметања тог свог избора потенцијалном издавачу. Најбољи (или најгори, зависно од угла посматрања) пример уплитања туристичког нивоа књижевне перцепције јесте када (приучени) преводилац бира књиге на основу бестселер-листе, доступне на први клик.

Ако, дакле, прихватимо тезу да је добро познавање језика и способност што је могуће шире оријентације у датој књижевности предуслов било ког покушаја дубинске перцепције, онда је у покушају да се на што је могуће кориснији и употребљивији начин прикаже живот мађарске књижевности на интернету, чак и у једном овако овлашном, просторно ограниченом прегледу најважнијих мађарских књижевних портала, можда најсврсисходније кренути од оних званичних, институционално маркираних сајтова, од оних интернетсајтова, дакле, иза којих својих ауторитетом стоје важне културне установе, иако би, наравно, главни контрааргумент оваквом приступу 
могао бити тај што онда у том случају постоји опасност да се исувише западне под утицај културног и књижевног mainstream-a, а на уштрб алтернативних, а често веома вредних појава чије боље упознавање омогућује управо интернет својом суштинском отвореношћу, доступношћу и демократичношћу. Одабир је добрим делом диктиран и досадашњим искуством рада са студентима хунгарологије на Филолошком факултету Универзитета у Београду, односно њиховим потребама и могућностима.

Кад је реч о дигиталним базама података, односно дигитализацији књижевне баштине, с обзиром на правило да седамдесет година након смрти аутора ауторска права застаревају, те да се, сходно томе, добар део класика мађарске литературе може наћи (и легално) у онлајн, односно рdf-форматима, можда није згорег осврнути се на то како стоје ствари са дигитализацијом дела живих или недавно преминулих истакнутих аутора, наших савременика. У том погледу предњачи један званични сајт, Digitális Irodalmi Akadémia (Дигитална књижевна академија), доступан на адреси https://pim.hu/ hu/dia, којем су многи истакнути савремени аутори са задовољством уступили своје текстове из простог разлога што је ствар истинског престижа ако вас замоле да будете његов члан. Другим речима, не може се тако лако стећи право да будете члан те виртуелне академије, само писци са изграђеним реномеом, са добром, вишедеценијском критичком рецепцијом, аутори превођени у свету стичу право на овај облик институционалног онлајн-присуства. Импресиван је низ аутора који су већим делом свог опуса заступљени на овој онлајн ризници текстова, којој се може приступити и без регистрације. Споменимо само неке: Ђерђ Конрад, Петер Естерхази, Ласло Краснахоркаи, Петер Надаш, Жужа Раковски, Ласло Мартон, Ђерђ Шпиро и многи други. Чињеница да су им дела доступна одиста широком кругу читалаца у свету, међутим, нимало не смањује продају њихових књига, чак ни продају нових издања њихових старијих дела, што је одиста феномен који би захтевао посебну анализу. Да и не говоримо о томе у коликој мери научницима, преводиоцима и уопште, људима који желе да пронађу одређено место у некој књизи или цитирају дотичног аутора, постојање овакве базе података олакшава посао. 
Дигитална књижевна академија је, иначе, само део једног већег „институционалног” књижевног сајта, познатог Петефијевог књижевног музеја у Будимпешти (Petöfi Irodalmi Múzeum), на адреcи https://pim.hu/, који је, заправо, много више од онога што његово име сугерише. У оквиру овог музеја, или боље речено, књижевног института, функционише и, са становишта популарисања мађарске књижевности у иностранству, изузетно важна Фондација за суфинансирање превода мађарске књижевности за стране језике, која иностраним издавачима у не малој мери финансијски помаже приликом објављивања мађарских наслова у преводима. Налази се на адреси: https://pim.hu/en/hungarian-books-and-translations-office.

Важна је и улога институција и организација које око себе окупљају ауторе млађе генерације, као што су Кружок Атиле Јожефа (József Attila Kör, скраћено JAK) на адреси http://jozsefattilakor.hu/, који се, поред вредне и квалитетне издавачке делатности, истиче и организацијом семинара, међу којима посебно треба нагласити семинар за (млађе) преводиоце мађарске књижевности (JAK Fordítótábor), који се сваког лета одржава у неком другом месту и на којем, као гости и предавачи, присуствују и најистакнутији савремени мађарски писци и критичари. Сличну улогу издавача и организатора семинара игра и Савез младих писаца (Fiatal Írók Szövetsége, скраћено FISZ), а увид у њихове активности може се стећи кликом на блог http:// fiatalirok.blog.hu/. Важно је истаћи да ови сајтови и блогови објављују и књижевну критику, потврђујући тиме да теза нашег критичара Владимира Арсенића да се озбиљна књижевна критика све више сели на интернет, важи и у мађарском окружењу (Арсенић 2017): „Познато је да је Нинова награда замишљена као награда критике. Редакција магазина именује жири и ту почињу све невоље, јер се књижевна критика у класичном смислу речи значајно променила. Она је, као што сви нажалост врло добро знамо, протерана из данашњих мејнстрим медија или је замањена пропагандом. Услед оваквог развоја догађаја преселила се на интернет." Критику и актуелне књижевне догађаје можемо пратити и ако одемо на сајт www.litera.hu.

У покушају да у мору официјелних и алтернативних интернетадреса посвећених књижевности већу тежину дамо овим првима, 
свакако се не смеју заобићи сајтови најважнијих и, из истраживачке визуре посматрано, најкориснијих великих библиотека у Мађарској, чији апдејтовани онлајн каталози, ауторски и предметни, омогућују брзу и квалитетну претрагу. По јединственој бази података и обавезним примерцима не само мађарских, већ и страних књига које се на било који начин баве мађарским језиком, књижевношћу и културом, сајт Народне библиотеке Мађарске „Сечењи” (Országos Széchenyi Könyvtár) на адреси www.oszk.hu пружа изврсну, брзу услугу свим заинтересованима (и на енглеском језику, наравно). Веома је користан и сајт Престоничке библиотеке „Ервин Сабо” (Fövárosi Szabó Ervin Könyvtár) на адреси www.fszek.hu.

Премда у данашњем ужурбаном, профитно оријентисаном свету, чији дух све више захвата и књижевност, периодика као да губи своју позицију „прве пробе”, „ватреног крштења” за младог писца, зарад оријентације у новијим токовима и тенденцијама у мађарској књижевности, ипак није лоше ако се редовно прати савремена часописна продукција. Данас већ сви озбиљни мађарски књижевни и критички часописи имају своје (добре) интернет-сајтове. Тако, рецимо, угледни печујски часопис за књижевност, критику и теорију Jelenkor има свој сајт на адреси www.jelenkor.net, који покрива и информације о издавачкој делатности. Од већих часописа и издавача из регионалних културних и универзитетских центара издваја се сегедински часопис Tiszatáj са сајтом www.tiszataj.hu. И часописи из дијаспоре полако почињу да хватају корак са временом. Тако угледни новосадски часопис Нíd, осим стандардним, апдејтованим сајтом на адреси www.hid.rs, може да се похвали и дигитализованом архивом, коју је додуше, нешто теже пронаћи на први клик, с обзиром на то да је у дигитализацији овог часописа свесрдну подршку пружио Завод за културу војвођанских Мађара, чија је официјелна интернет адреса www.vmmi.org, на којој се налази и ова права мала ризница дигитализованих бројева часописа Híd. И најзад, али никако не и на последњем месту, кад је реч о овом кратком и селективном приказу мађарских периодичних публикација доступних на интернету, мора се поменути и веома утицајни друштвенополитичко-књижевни недељник Élet és Irodalom (у мађарској познат по скраћеници ÉS), 
који је, у свом пуном обиму, истина, само регистрованим корисницима, доступан на адреси www.es.hu.

И етаблирани мађарски издавачи у земљи и иностранству имају, разуме се, одличне, прегледне и, са становишта читалаца, али и страних издавача који размишљају о евентуалном превођењу и издавању мађарских наслова, веома корисне сајтове. Поменимо овде само два, у последње време, највећа, најпродуктивније и најутицајнија озбиљна издавача, Magvető из Будимпеште (www. magveto.hu) и Kalligram из Братиславе (чији огранак постоји и у Будимпешти), доступан на адреси www.kalligram.com, чија локализација не треба да завара, јер уопште није реч о некаквом мањинском или „завичајном" издавачу, већ, напротив, о издавачкој кући која се са већ поменутом кућом Magvetö, у последње време напросто утркује ко ће издати квалитетније књиге савремених мађарских аутора. Осим тога, Kalligram је покренуо и едицију (заборављених) класика, а ушао је и у амбициозни пројекат издавања сабраних дела једног од најпродуктивнијих мађарских класика с почетка двадесетог века, Ђуле Крудија. Кад је реч о мањинској мађарској књижевности, посебно оној која настаје на нашим просторима, најутицајнији издавач књига које пишу мађарски писци из Војводине већ деценијама је новосадски Форум (Forum). С обзиром на то да Форум, поред оригиналних дела мађарских писаца из Војводине те мађарских превода српских дела, неретко објављује и српске преводе дела мађарских писаца, речнике, па и двојезична издања поезије (рецимо, поезију Ендреа Адија, Атиле Јожефа и Миклоша Раднотија у преводу Данила Киша), а да је, због недостатка њихових књижара дистрибуција практично пресељена на интернет и онлајн-наручивање, није згорег овде навести и њихову интернет адресу: www.forumliber.rs. Релативно нова, амбициозна мађарска мањинска издавачка кућа зЕтна (zEtna) из Сенте, кад је купопродаја и рекламирање у питању, такође послује преко интернета. На њиховом сајту www.zetna.org се, осим о њиховим издањима, може сазнати понешто и о занимљивим двојезичним, српско-мађарским списатељским пројектима.

Ако се сада, за сам крај овог кратког прегледа, одмакнемо од официјалних сајтова институција, часописа и издавача и ступи- 
мо на алтернативно тле онога што би требало да је сама суштина „књижевне интернет-демократије”, односно у сферу књижевне расправе на интернет-агори (додуше, понешто од рестриктивности и овде још остаје, јер коментаре анонимних читалаца ћемо ипак овога пута занемарити), посебну пажњу посветићемо, да помало фриволно парафразирамо Ничеа, самој расправи о користи и штети интернета за књижевност, из пера или уста несумњивих књижевних и научнопедагошких ауторитета. На интернету се, дакле, у протеклих десетак година може пратити кретање тог, назовимо га тако, мета-дискурса о књижевности на интернету. Ограничићемо се овде на свега два важна актера мађарске књижевне сцене и њихово мишљење о односу интернета и књижевности. Иако су генерацијска уопштавања увек врло опасна и незахвална, могло би се рећи да ова двојица актера новије мађарске књижевне сцене представљају и став двеју различитих генерација о односу интернета и књижевности.

Доајен и enfant terrible мађарске књижевности XX века, велики песник, бунтовник и јавни интелектуалац Ђерђ Фалуди (Faludy György, 1910-2006), пред сам крај свог живота, 2006. године, у интервјуу недељнику hvg изразио је велику скепсу у могућност да књижевност као таква уопште некако преживи XX столеће. За то је, по Фалудијевом мишљењу, крива телевизија, а посредно, и интернет (мада је за ових десет година интернет постао много доступнији него у време Фалудијевих последњих овоземљаских дана, па је тешко претпоставити како би, да је којим случајем доживео 105. рођендан, Фалуди данас о томе размишљао). Иако је у младости веровао да ће радио, као радикално нови медиј, „убити“ књижевност, то се ипак није десило, напротив, у неким елементима, радио је чак помогао и њеном пропагирању. Оно што радио није успео, успела је, међутим, по Фалудијевом мишљењу (Faludy 2006), телевизија, а појава и јачање интернета ће, тврдио је он, само потврдити ту чињеницу. Требало би, међутим, скренути пажњу да је ова констатација изнета у оквиру ширег контекста интервјуа који се, између осталог, бави и питањима квалитета савремене мађарске књижевности, који је, по мишљењу Ђерђа Фалудија, веома лош. Уосталом, сам интервју носи наслов „Harmadrendű a honi magyar irodalom“ („Овдашња је мађарска 
књижевност трећеразредна"). Критичари и критизери би рекли да је читав интервју доказ да се некадашњи бунтовник претворио у џангризавог старца који, попут толиких људи који зађу у неке године, некритички жали за прохујалим временима „када је све било боље“. Па ипак, Фалудијево мишљење не сме се занемарити, преко њега се не може тек тако прећи, чак и ако се не слажемо са њим.

А како један универзитетски професор средње генерације, Балаж Физфа (Füzfa Balázs), историчар књижевности, теоретичар, али и један од најутицајнијих методичара наставе мађарске књижевности у школи, иначе један од најгласнијих и најутицајнијих заговорника коришћења модерних технологија у настави, односно наставник метода за XXI век, гледа на овај проблем? Аутор веома модерне, чак би се могло рећи и револуционарно модерне серије уџбеника књижевности за средњу школу, Физфа у интервјуу знаковитог наслова „Betűfaló fiatalok, avagy kell-e még az irodalom a diákságnak?“ („Млади гутачи слова или да ли је ђацима још увек потребна књижевност?"), на питање воли ли данашња омладина уопште да чита, воли ли лепу књижевност, овако одговара (Füzfa 2016): „Могуће је да читају мање белетристике него што су то чинили млади пре неколико деценија, али сам сасвим сигуран да су много већи гутачи слова. Ако узмемо у обзир колико смс-ова, имејлова, чет-порука, фејсбук-објава напишу и прочитају дневно, ту тврдњу можемо доказати и без баратања неким егзактним бројкама." (сви цитати и парафразе преузети су из овог интернет-интервјуа). Много је већи проблем, по његовом мишљењу, општа друштвена клима и то колики значај наша тржишно оријентисана епоха уопште придаје књижевности, колики је данашњи друштвени престиж књижевности као уметности и заната. У данашњој ери (све)опште доступности информација, по мишљењу овог врсног и иновативног методичара, требало би једном за свагда одбацити књижевноисторијски приступ предавању књижевности, који је у основи превазиђен, досадан, и нагласак ставља на чињенице које се заиста могу наћи невероватно брзо. Уместо тога, сматра он, „[...] потребна нам је настава која подстиче на размишљање, на сагледавање проблема, и онда ће нам бити јасно да онај ко боље и прецизније, са већим разумевањем чита песму, тај ће боље разумети и математички 
задатак и лекцију из биологије, односно свет око себе уопште. То јест, у крајњој линији, лакше ће моћи да разликује истину од лажи." Кад је реч о употреби интернета, јутјуба и паметних телефона на часу, он сматра да је апсолутно контрапродуктивно забрањивати њихову употребу у школи. Уместо, како се изразио, „суманутог, средњовековног војевања око уџбеника“ требало би што пре све школе опремити супербрзим бежичним интернетом, брзином светлости обучити професоре да се сналазе у основама IT-ja. „На то би требало трошити новац, а не доживљавати школу као гласноговорника старомодних и превазиђених идеја. Већ десет година понављам да је један таблет јефтинији од комплета уџбеника за други разред. Потребно је само онлајн градиво и готово. Тржиште уџбеника одржавају у животу само економска принуда и интереси уџбеничког лобија - и, наравно, идеолошки циљеви сваке власти, не будимо лицемери, рецимо то отворено. Интернет уопште не смањује склоност према читању, напротив, она је подстиче и развија. Не вреди о томе расправљати. “ Кад је реч о премошћавању генерацијског јаза између наставника и ученика, Балаж Физфа предлаже особену врсту компромиса, која би се састојала у томе да млађим нараштајима приближимо књижевност ранијих епоха, ону у којој смо ми толико уживали, тако што ћемо победити свој естетички елитизам, те и сами одвојити мало времена за читање оне књижевности која њих, у великој већини, толико интересује (епска фантастика, Џоан Ролинг итд.).

Могло би се рећи да аутори уџбеника и методичари млађе генерације пишу и делају на трагу идеја које је својим уџбеницима и уопште, читавим својим јавним ангажманом, поставио Балаж Физфа. Од истакнутијих аутора који су на неки начин изашли из „Физфиног шињела“, свакако се мора поменути Пал Нењеи (Nényei Pál), аутор, ако се у књижевности уопште сме употребити таква формулација, хит-уџбеника Az irodalom visszavág ('Књижевност узвраћа ударац'), у којем на забаван, примамљив, на моменте наизглед и неозбиљан и „мангупски“ начин, бави светском и мађарском књижевношћу од почетака до данас.

И најзад, но свакако не и на последњем месту, у овом кратком, информативном прегледу који ни у ком случају не претендује на свео- 
бухватност, требало би поменути и барем два главна књижевна блога који, иако алтернативни и не баш увек поуздани извори информација и тумачења, ђацима ипак помажуда се снађу учесто несавладиво обимном средњошколском градиву из књижевности, док заинтересованим читаоцима пружају кратке и не увек баш претерано стручне критике и коментаре новообјављених књига. У том смислу, мађарски ученици средњих, па и основних школа, чести су посетиоци сајта www.sulinet. hu, док читаоци који не желе да се превише замарају „тешким“, стручним језиком засићеним критикама, неретко одлазе на блог irodalmi. blog.hu. Важан сајт који на известан начин представља плодотворан и подстицајан спој алтернативне и официјелне критике јесте и сајт www. barkaonline.hu, на којем су, не тако давно, објављене критике управо поменутог Нењеијевог уџбеника из пера чак троје критичара, у већ уходаној рубрици која се зове „Троје о једној новој књизи“. Занимљиво је да једна од те три критике носи знаковити наслов „Batman az ókorban“ - „Бетмен у антици”. Упркос помало ироничном наслову, аутор те критике, Иштван Лакатош (Lakatos 2016), Нењеијев уџбеник узима као доказ да је спој древних тема и савремене поп-културе и те како могућ. А читалац кога занима шта је сам аутор уџбеника на промоцији своје књиге рекао о свом схватању предавања књижевности, може да посети блог www.konyves.blog.hu, где ће већ из наслова („Књижевност је питање живота и смрти, баш као и љубав“), наслутити који су мотиви нагнали аутора, који је и сам гимназијски наставник, да на један веома необичан, на моменте чак и „скандалозан“ начин, књижевност учини пријемчивијом и узбудљивијом за нове генерације.

\section{Литература}

Арсенић, Владимир. „170 романа за друга Нина“. http://proletter.me/portfolio/170romana-za-druga-nin-a/, 2017. (последњи пут приступљено 25. фебруара 2017. године)

Faludy György. „Harmadrendú a honi magyar irodalom” [Овдашња је мађарска књижевност трећеразредна]. http://hvg.hu/hetilap/2006.22HVGFriss126/20062 2HVGFriss126, 2006. (последњи пут приступљено 23. фебруара 2017. године).

Fúzfa Balázs. „Betűfaló fiatalok, avagy kell-e még az irodalom a diákságnak?” [Млади гутачи слова или да ли је ђацима још увек потребна књижевност?]. http:// 
zaol.hu/kultura/betufalo-fiatalok-avagy-kell-e-meg-az-irodalom-a-diaksagnakinterju-a-mai-magyar-irodalomoktatas-problemairol-nehezsegeirol-1777493, 2016. (последњи пут приступљено 22. фебруара 2017. године)

Kiss Orsi. „Az irodalom ugyanúgy élet és halál kérdése, mint a szerelem” [Књижевност је питање живота и смрти, баш као и љубав]. http://konyves.blog.hu/2015/11/13/ az_irodalom_alfele_bemutato, 2015. (последњи пут приступљено 26. фебруара 2017. године)

Lakatos István. „Batman az ókorban”. http://www.barkaonline.hu/futtyoges-esnahatozas/5331-az-irodalom-visszavag---harman-egy-konyvrol, 2016. (последњи пут приступљено 24. фебруара 2017. године)

Szegedy-Maszák Mihály. A megértés módozatai: fordítás és hatástörténet [Модалитети разумевања: превод и историјат утицаја]. Akadémiai Kiadó, Budapest, 2003.

\title{
Marko Cudic \\ University of Belgrade \\ Faculty of Philology
}

\section{THE MOST IMPORTANT HUNGARIAN LITERARY INTERNET PORTALS}

\begin{abstract}
Summary
This paper analyzes the relationship between internet and Hungarian literature, with special focus on the most important web sites dedicated to classic, modern and contemporary Hungarian literature. The main focus of this, primarily informative type of paper, are mostly official web sites such as The Digital Literary Academy (Digitális Irodalmi Akadémia), which contains the digitalized works of chosen (canonized) contemporary authors. Apart from this, the paper focuses on more alternative literary web sites, such as blogs, which have a more "democratic" nature (in the sense that practically any reader can express his/her opinion on a given book), but also on forums and blogs which offer alternative readings of classical works. Special attention in the paper is paid to online Hungarian literary journals, as well as to the attitude of Serbian students of Hungarian language, literature and culture towards Hungarian literature on the internet.
\end{abstract}

Key words: Hungarian literature, internet, literary blogs, canonization, alternative criticism 